\title{
Complete genome sequence of the fish pathogen Flavobacterium psychrophilum ATCC $49418^{\top}$
}

\author{
Anson KK Wu', Andrew M Kropinski ${ }^{1}$, John S Lumsden ${ }^{1}$, Brian Dixon ${ }^{2}$ and Janet I Maclnnes ${ }^{1 *}$
}

\begin{abstract}
Flavobacterium psychrophilum is the causative agent of bacterial cold water disease and rainbow trout fry mortality syndrome in salmonid fishes and is associated with significant losses in the aquaculture industry. The virulence factors and molecular mechanisms of pathogenesis of F. psychrophilum are poorly understood. Moreover, at the present time, there are no effective vaccines and control using antimicrobial agents is problematic due to growing antimicrobial resistance and the fact that sick fish don't eat. In the hopes of identifying vaccine and therapeutic targets, we sequenced the genome of the type strain ATCC 49418 which was isolated from the kidney of a Coho salmon (Oncorhychus kisutch) in Washington State (U.S.A.) in 1989. The genome is 2,715,909 bp with a G+C content of $32.75 \%$. It contains 6 rRNA operons, 49 tRNA genes, and is predicted to encode 2,329 proteins.
\end{abstract}

Keywords: Aerobic, Gram negative, Psychrotolerant, Fish pathogen, Flavobacterium, Bacterial cold water disease, Rainbow trout fry mortality syndrome

\section{Introduction}

Flavobacterium psychrophilum is a Gram-negative pathogen that infects all species of salmonid fish and has been found to also infect eel and three species of cyprinids [1-3]. It causes bacterial cold water disease (BCWD) and rainbow trout fry mortality syndrome (RTFS) in fish and is responsible for significant losses in the salmonid aquaculture industry [1]. Water temperature plays a key role in the infection and development of disease [4] which occurs between $4-16^{\circ} \mathrm{C}$ and is most prevalent at $10^{\circ} \mathrm{C}$ or below [5]. It was originally thought to be limited to North America [6] but it is now recognized in almost every country in Europe, in some parts of Asia, and in Australia [1,7].

Three serotypes and two biovars of $F$. psychrophilum have been described $[7,8]$. In addition, molecular analysis of the population structure of this bacterium suggests that there are a number of distinct lineages [7]. It has been speculated that some strains are species specific [9] while others are location specific [10]. Some strains have also been observed to cause only either BCWD or RTFS [7]. A recent study in Japan showed multiple sequence

\footnotetext{
*Correspondence: macinnes@uoguelph.ca

1 Department of Pathobiology, Ontario Veterinary College, University of Guelph, 50 Stone Road East, Guelph, Ontario N1G 2W1, Canada

Full list of author information is available at the end of the article
}

types infecting ayu (Plecoglossus altivelis) in a closed lake environment [11]. It is also known that phase variation can occur where the colonial phenotype changes between "rough" and "smooth", perhaps to help in evasion of the immune system [12]. Generally F. psychrophilum populations are heterogeneous; however, a recent study showed closely related epidemic clones infecting rainbow trout (Oncorhynchus mykiss) in Nordic countries [13]. To date, only one genome sequence [14] of F. psychrophilum has been reported and sequences of other strains are required to gain insight into the molecular mechanisms of virulence and why some strains are more virulent than others. Here we present a summary of classification and features of the F. psychrophilum type strain ATCC 49418 $(=$ DSM $3660=\mathrm{NCMB}=1947=$ LMG $13179=$ ATCC 49418) [15] together with a description of the complete genome and its annotation.

\section{Organism Information \\ Classification and Features}

The taxonomy of F. psychrophilum has been changed many times since Borg (1960) classified it as Cytophaga psychrophila based on its biochemical properties [16]. It was later reclassified within the genus Flexibacter based on DNA homology and renamed to Flexibacter psychrophilus [17]. Most recently, it was reclassified to the genus 
Table 1 Classification and general features of Flavobacterium psychrophilum ATCC $49418^{\top}$

\begin{tabular}{|c|c|c|c|}
\hline MIGS ID & Property & Term & Evidence code $^{a}$ \\
\hline & Current Classification & Domain Bacteria & TAS [24] \\
\hline & & Phylum Bacteroidetes & TAS [25] \\
\hline & & Class Flavobacteriia & TAS $[26,27]$ \\
\hline & & Order Flavobacteriales & TAS [23] \\
\hline & & Family Flavobacteriacea & TAS $[18,22]$ \\
\hline & & Genus Flavobacterium & TAS $[18,28]$ \\
\hline & & Species Flavobacterium psychrophilum & TAS [18] \\
\hline & & Type strain ATCC 49418 & TAS $[15,18]$ \\
\hline & Gram stain & Negative & TAS [15] \\
\hline & Cell shape & Rods & TAS [15] \\
\hline & Motility & Gliding & TAS [15] \\
\hline & Sporulation & Non-spore forming & TAS [18] \\
\hline & Temperature range & Psychrotolerant $\left(4^{\circ} \mathrm{C}\right.$ to $\left.30^{\circ} \mathrm{C}\right)$ & TAS $[15,29,30]$ \\
\hline & Optimum temperature & $15-20^{\circ} \mathrm{C}$ & TAS [31,32] \\
\hline & Carbon source & Non-saccharolytic & TAS [18] \\
\hline & Energy source & Chemoorganotroph & TAS [18] \\
\hline & Terminal electron receptor & Oxygen & NAS [33] \\
\hline MIGS-6 & Habitat & Host & TAS [15] \\
\hline MIGS-6.3 & Salinity & Usually grows in $0.5 \%$ and stops at $1.0 \%$ & TAS $[8,15]$ \\
\hline MIGS-22 & Oxygen & Aerobic & TAS [15] \\
\hline MIGS-15 & Biotic relationship & Obligate pathogen of fish (but can survive in freshwater for several months) & NAS [7] \\
\hline MIGS-14 & Pathogenicity & Salmonid fishes, eel, and three species of Cyprinids & $\operatorname{TAS}[1,15]$ \\
\hline MIGS-4 & Geographic location & Worldwide including North America, Europe, and Asia & TAS $[1,7]$ \\
\hline MIGS-5 & Sample collection time & 1989 & TAS [15] \\
\hline MIGS-4.1 MIGS-4.2 & Latitude - Longitude & Not reported & \\
\hline MIGS-4.3 & Depth & Not Reported & \\
\hline MIGS-4.4 & Altitude & Not Reported & \\
\hline
\end{tabular}

${ }^{a}$ Evidence codes - IDA: Inferred from Direct Assay; TAS: Traceable Author Statement (i.e., a direct report exists in the literature); NAS: Non-traceable Author Statement (i.e., not directly observed for the living, isolated sample, but based on a generally accepted property for the species, or anecdotal evidence). These evidence codes are from of the Gene Ontology project [40].

Flavobacterium and renamed to F. psychrophilum based on DNA-RNA hybridization [18]. The genus name was derived from the Latin flavus meaning "yellow" and the ancient

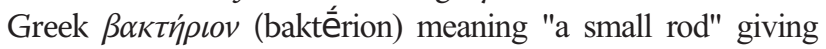
the Neo-Latin word Flavobacterium, a "small yellow rod- shaped bacteria" [19,20]. The species name was derived from

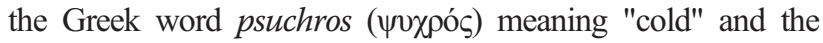
Neo-Latin word philum meaning "loving" which translates to "cold loving" [19,20]. The genus Flavobacterium consists of 119 recognized species [21]; it belongs to the family
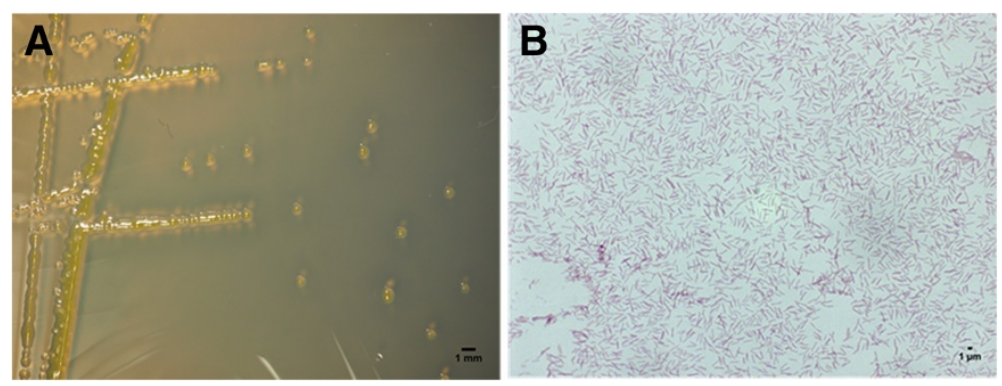

Figure 1 Colonial and cellular morphology of $F$. psychrophilum ATCC $49418^{\top}$ grown on cytophaga agar (A) and Gram stained (B) (1000x). 


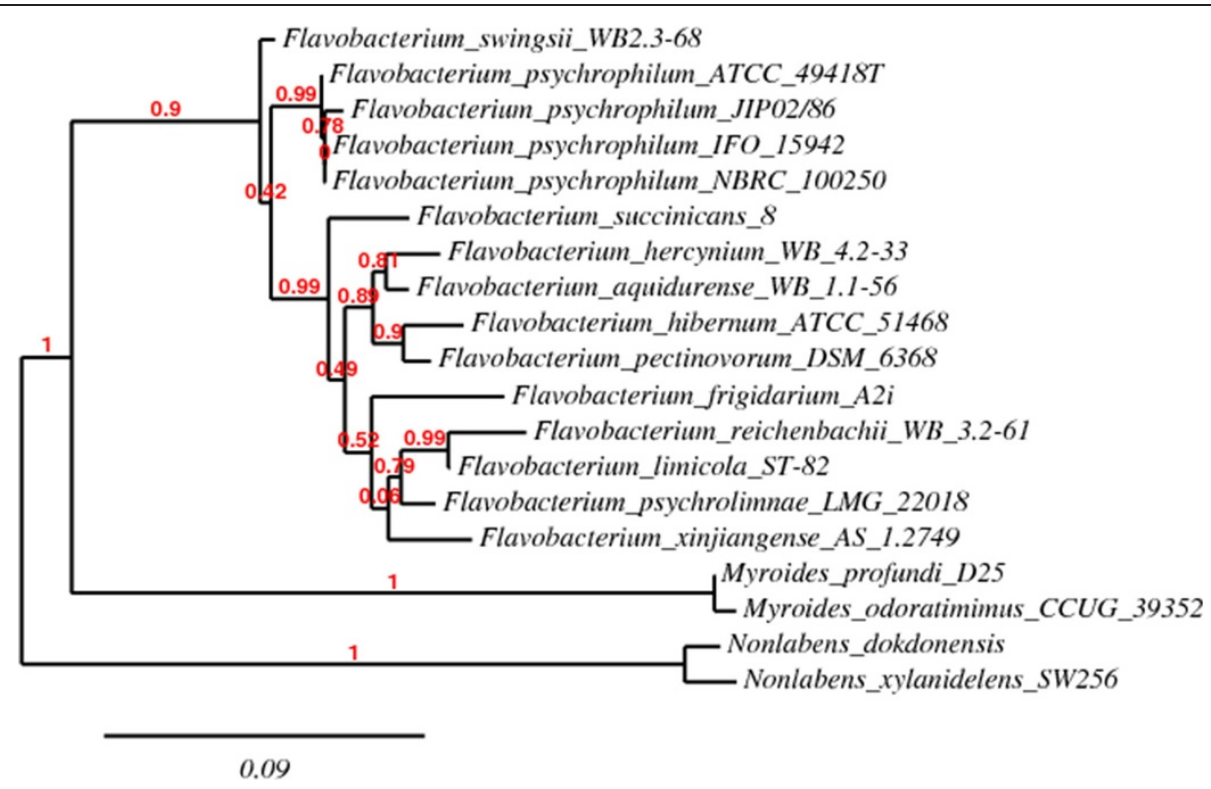

Figure 2 Phylogenetic tree displaying the relationship between $F$. psychrophilum ATCC $49418^{\top}$ and selected strains and species of the same genus. Other genera from the family Flavobacteriaceae were used as an out group. The phylogenetic tree was constructed using the "One Click" mode with default settings in the Phylogeny.fr platform [41]. This pipeline uses four different programs including MUSCLE [42], Gblock [43], PhyML [44], and TreeDyn [45]. The numbers above the branches are tree support values generated by PhyML using the aLRT statistical test.

Flavobacteriaceae $[18,22]$ and the order Flavobacteriales [23] (Table 1).

F. psychrophilum ATCC $49418^{\mathrm{T}}$ was isolated in Washington State (U.S.A) from the kidney of a young Coho salmon (Oncorhynchus kisutch) in 1989 [15]. It is a Gram negative, aerobic, and psychrotolerant microorganism [7] (Figure 1). When grown on cytophaga agar, bright yellow, smooth, discreet, circular, convex, and nonadherent colonies are produced [8]. The optimal growth temperature is between $15-20^{\circ} \mathrm{C}[31,32]$ with no growth occurring at $30^{\circ} \mathrm{C}$ or greater $[15,29,30]$. Microscopically it is rod-shaped measuring 3-7 $\mu \mathrm{m}$ long and 0.3-0.5 $\mu \mathrm{m}$ wide [8]. Although gliding motility has been reported the mechanism is yet to be elucidated since $F$. psychrophilum does not appear to use pili or polysaccharide secretion $[1,15,17]$. API-ZYM tests show that it can produce alkaline phosphatase, esterase, lipase, leucine, valine, and cysteine arylamidases, trypsin, acid phosphatase, and napthol-AS-BI phosphohydrolase [8]. In addition, it has been reported that it can produce catalase $[29,34]$ and oxidase [17], hydrolyze tributyrin and proteins including casein, gelatin, elastin, albumin, collagen, and fibrinogen [35-39]. Although many strains including ATTC $49418^{\mathrm{T}}$ cannot metabolize simple and complex sugars [1] a recent study has shown that some strains are able to produce two or more sugar degrading enzymes including alpha-galactosidase, beta-galactosidase, alpha-glucosidase, beta-glucosidase, and $\mathrm{N}$-acetyl-betaglucosaminidase [8].
A phylogentic tree was constructed using the $16 \mathrm{~S}$ rRNA sequences of $F$. psychrophilum ATCC $49418^{\mathrm{T}}$, selected strains and species of the same genus, as well as selected species of other genera belonging to the family Flavobacteriaceae (Figure 2). The four F. psychrophilum strains are grouped together in the tree with ATCC

\section{Table 2 Project information}

\begin{tabular}{lll}
\hline MIGS ID & Property & Term \\
\hline MIGS-31 & Finishing quality & Finished \\
MIGS-28 & Libraries used & None \\
MIGS-29 & $\begin{array}{l}\text { Sequencing } \\
\text { platforms }\end{array}$ & PacBio RS II \\
MIGS-31.2 & Fold coverage & 184x \\
MIGS-30 & Assemblers & HGAP workflow \\
MIGS-32 & $\begin{array}{l}\text { Gene calling } \\
\text { method }\end{array}$ & NCBI Prokaryotic Genome Annotation \\
& Locus Tag & FPG3 \\
& $\begin{array}{l}\text { GenBank ID } \\
\text { GenBank Date of }\end{array}$ & CP007207 \\
& Selease & PRJember 12, 2014 \\
& BioProject ID & PRJ236029 \\
& GOLD ID & Gi0074339 \\
& Project relevance & Fish Pathogen \\
& Source Material & ATCC \\
Identifier & \\
\hline MIGS-13 & & \\
\hline
\end{tabular}


$49418^{\mathrm{T}}$ being most similar to JIP02/86 (ATCC 49511), the only other strain to have a complete genome sequence.

\section{Genome sequencing information}

Genome project history

The complete genome sequence and annotation data of F. psychrophilum ATCC $49418^{\mathrm{T}}$ have been deposited in DDBJ/EMBL/GenBank under the accession number
CP007207. Sequencing and assembly steps as well as finishing were performed at McGill University and Génome Québec Innovation Centre. Annotation was performed using the NCBI Prokaryotic Genome Annotation Pipeline [46] and manually edited in Kodon (Applied Maths, Austin, TX). Table 2 presents a summary of the project information and its association with MIGS version 2.0 compliance [47].

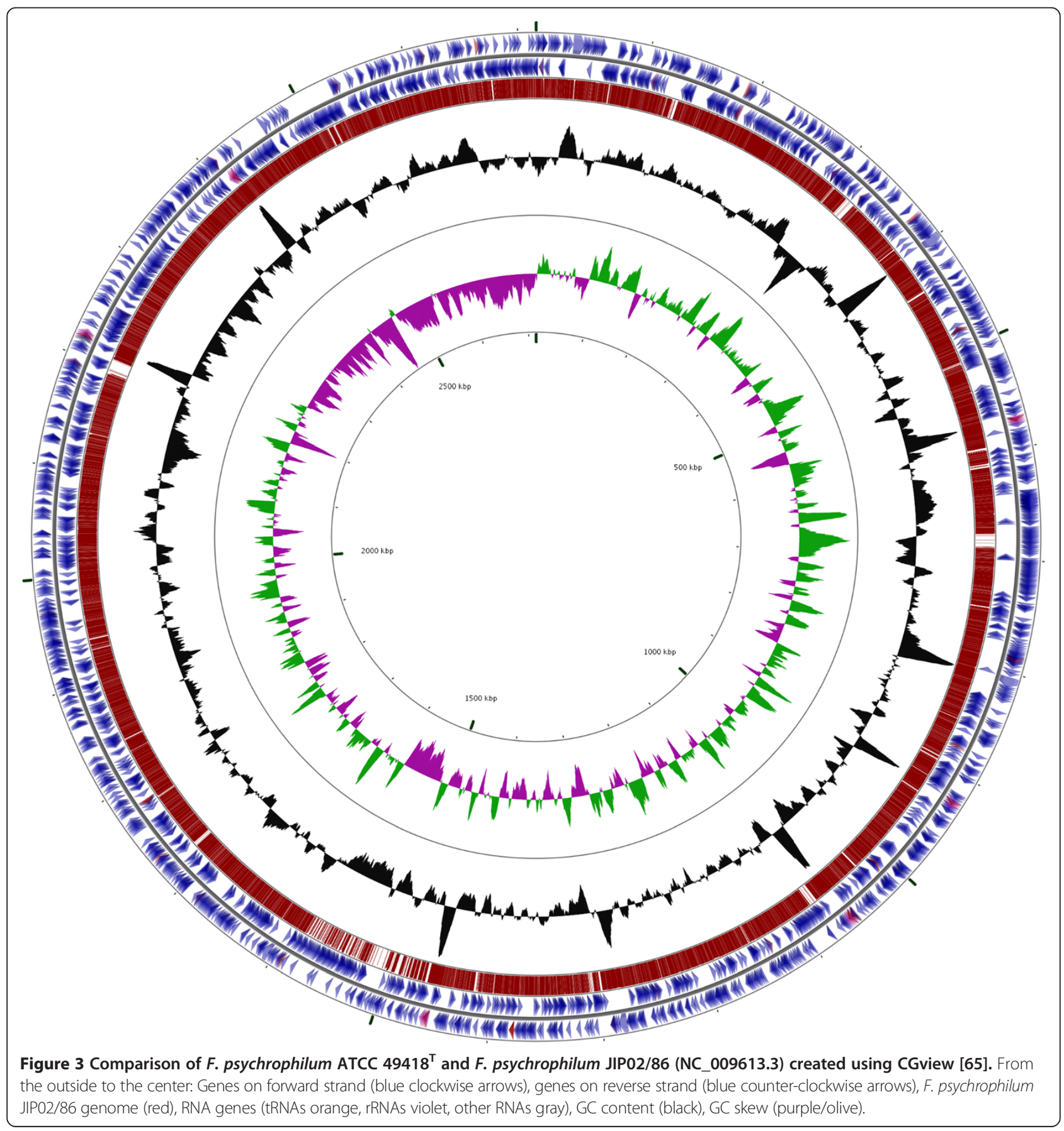




\section{Growth conditions and DNA isolation}

F. psychrophilum ATCC $49418^{\mathrm{T}}$ was originally obtained from the American Type Culture Collection [15] and was stored in a frozen glycerol stock $(15 \%)$ at $-70^{\circ} \mathrm{C}$. It was grown for 4 days at $12^{\circ} \mathrm{C}$ on modified cytophaga agar [48] containing $0.06 \%(w / v)$ tryptone, $0.05 \%$ yeast extract, $0.02 \%$ beef extract, $0.02 \%$ sodium acetate, $0.05 \%$ anhydrous calcium chloride, $0.05 \%$ magnesium chloride, $0.05 \%$ potassium chloride, $1.5 \%$ agar, $0.02 \%$ gelatin, $\mathrm{pH} 7.5$. Well isolated colonies were used for genomic DNA isolation. Colonies $\left(\sim 4 \mathrm{~mm}^{3}\right)$ were picked using a sterile toothpick and lysed using modified B1 (1 $50 \mathrm{mM}$ Tris. $\mathrm{Cl}, 50 \mathrm{mM}$ EDTA, 0.5\% Tween ${ }^{\oplus}-20,0.5 \%$ Triton $\left.\mathrm{X}-100, \mathrm{pH} 8.0\right)$ and B2 (750 mM NaCl, $50 \mathrm{mM}$ MOPS, 15\% isopropanol, $0.15 \%$ Triton X-100, pH 7.0) buffers. DNA was purified and eluted using the QIAGEN Plasmid Midi Kit (Qiagen, Germany) following manufacturer's protocol.

\section{Genome sequencing and assembly}

Genome sequencing of F. psychrophilum ATCC $49418^{\mathrm{T}}$ was performed using a PacBio RS II instrument. The reads were automatically processed through the Single Molecule Real Time (SMRT) software suite using the Hierarchical Genome Assembly Processing (HGAP) pipeline [49]. The resulting reads $(580,625,890 \mathrm{bp}$ in total) were filtered and the longest reads with $20 \mathrm{x}$ coverage were selected as seeds for constructing preassemblies. The preassemblies were constructed by aligning the short reads to the long reads

Table 3 Nucleotide content and gene count levels of the genome

\begin{tabular}{lrr}
\hline Attribute & \multicolumn{2}{c}{ Genome (total) } \\
\cline { 2 - 3 } & Value & \% of total \\
\hline Genome size (bp) & $2,715,909$ & $100.00 \%$ \\
DNA coding (bp) & $2,336,075$ & $86.01 \%$ \\
G+C content (bp) & 889,460 & $32.75 \%$ \\
DNA scaffolds & 1 & \\
Total genes & 2397 & $100.00 \%$ \\
Protein-coding genes & 2,329 & $97.00 \%$ \\
RNA genes & 68 & $2.84 \%$ \\
Pseudo genes & 24 & $1.00 \%$ \\
Genes in internal clusters & $N / D^{\mathrm{a}}$ & \\
Genes with function prediction & 1881 & $78.47 \%$ \\
Genes assigned to COGs & 1,438 & $60.00 \%$ \\
Genes assigned Pfam domains & 1,933 & $80.64 \%$ \\
Genes with signal peptides & 236 & $9.85 \%$ \\
Genes with transmembrane helices & 506 & $21.11 \%$ \\
Number of CRISPR candidates & 8 & \\
Confirmed CRISPR(s) & 1 & \\
Unconfirmed CRISPR(s) & 7 & \\
\hline
\end{tabular}

${ }^{\mathrm{a}} \mathrm{N} / \mathrm{D}=$ not determined. (seeds). Each read was mapped to multiple seeds using BLASTR [50]. In total there were 8073 long sequences totaling 90,000,401 bp with an average length of $11148 \mathrm{bp}$ and 162,858 bp short sequences totaling 490,625,489 bp with an average length of $3013 \mathrm{bp}$. Since errors in PacBio are random, aligning the multiple short reads onto the long reads allows the correction of errors in the long reads. The optimal number of sequences to be mapped onto the seeds is controlled by the "-bestn" parameter and the optimal number was determined to be 12 . The preassembled reads for the seeds are generated using PBDAG-Con [51] to create corrected consensus sequences in addition to quality analysis of the seeds. This script uses multiple sequence alignments and a directed acyclic graph to produce the best consensus reads possible. It does so by eliminating the insertion and deletion errors generated during the sequencing process. In addition, it avoids generating chimeric sequences (sequences with artifacts) for

Table 4 Number of genes associated with the $\mathbf{2 5}$ general COG functional categories

\begin{tabular}{|c|c|c|c|}
\hline Code & Value & $\%$ of total & Description \\
\hline J & 140.0 & 9.66 & Translation \\
\hline A & 0.0 & 0.00 & RNA processing and modification \\
\hline K & 72.0 & 4.97 & Transcription \\
\hline $\mathrm{L}$ & 96.0 & 6.63 & Replication, recombination and repair \\
\hline$B$ & 0.0 & 0.00 & Chromatin structure and dynamics \\
\hline D & 18.0 & 1.24 & Cell cycle control, mitosis and meiosis \\
\hline Y & 0.0 & 0.00 & Nuclear structure \\
\hline V & 41.0 & 2.83 & Defense mechanisms \\
\hline $\mathrm{T}$ & 32.0 & 2.21 & Signal transduction mechanisms \\
\hline M & 145.0 & 10.01 & Cell wall/membrane biogenesis \\
\hline N & 4.0 & 0.28 & Cell motility \\
\hline Z & 1.0 & 0.07 & Cytoskeleton \\
\hline W & 0.0 & 0.00 & Extracellular structures \\
\hline$U$ & 31.0 & 2.14 & Intracellular trafficking and secretion \\
\hline $\mathrm{O}$ & 61.0 & 4.21 & $\begin{array}{l}\text { Posttranslational modification, protein } \\
\text { turnover, chaperones }\end{array}$ \\
\hline C & 75.0 & 5.16 & Energy production and conversion \\
\hline G & 51.0 & 3.52 & Carbohydrate transport and metabolism \\
\hline E & 120.0 & 8.28 & Amino acid transport and metabolism \\
\hline $\mathrm{F}$ & 54.0 & 3.73 & Nucleotide transport and metabolism \\
\hline$H$ & 96.0 & 6.63 & Coenzyme transport and metabolism \\
\hline I & 63.0 & 4.35 & Lipid transport and metabolism \\
\hline $\mathrm{P}$ & 70.0 & 4.83 & Inorganic ion transport and metabolism \\
\hline Q & 26.0 & 1.79 & $\begin{array}{l}\text { Secondary metabolites biosynthesis, } \\
\text { transport and catabolism }\end{array}$ \\
\hline $\mathrm{R}$ & 164.0 & 11.32 & General function prediction only \\
\hline S & 89.0 & 6.14 & Function unknown \\
\hline- & 1050 & 43.80 & Not in COGs \\
\hline
\end{tabular}


assembly because chimeric reads will have no or low short sequence coverage. At the end of the process, only the best preassembled reads without artifacts are sent to the assembler [52].

After quality analysis and eliminating some of the preassembled reads by PBDAG-Con, the remaining 6,009 reads were fed into the Celera assembler which uses an overlap-layout-consensus strategy [49]. A total of 2 contigs were generated with sizes $1,647,861 \mathrm{bp}$ and 1,076,634 bp. These contigs underwent an additional polishing step where they were compared against the raw reads and any artifacts found were removed [49]. The final consensus generated was analyzed and improved by using the multiread consensus algorithm Quiver. Quiver takes the two contigs and the initial sequencing reads and maps the reads onto the assemblies [49]. It then disregards the alignment between the reads and the assemblies and a consensus is created independently from the reads allowing it to remove any fine-scale errors made by the Celera assembler [52]. An approximate copy of the consensus sequences is then generated by Quiver which makes insertions and deletions and those that improve the maximum likelihood are applied to the initial consensus sequence [53]. The two final contigs generated by Quiver were $1,648,613 \mathrm{bp}$ and $1,077,094 \mathrm{bp}$.

The two contigs underwent a finishing process using SeqMan Pro (DNASTAR Inc., Madison, WI). The two contigs were collapsed into one and the sequence was then opened in a region homologous to the Ori of $F$. psychrophilum JIP02/86 resulting in another two contigs.
These were resealed using SeqMan Pro to create one final complete contig.

\section{Genome annotation}

The NCBI Prokaryotic Genome Annotation Pipeline was used to predict protein coding genes, structural RNAs (5S, 16S, 23S), tRNAs, and small non-coding RNAs [54]. Protein coding genes were predicted by protein alignment using ProSplign [55] where only complete alignments with $100 \%$ identity to a reference protein are kept for final annotation. Frameshifted or partial alignments were further analyzed by GeneMarkS+ [56] for further analysis and gene prediction. A BLASTN search against a reference set of structural RNA genomes from the NCBI Reference Sequence Collection was conducted to find the structural RNAs since they are highly conserved in closely related prokaryotes. tRNAscan-SE was used to identify the tRNAs [57]. Small RNAs were predicted using a BLASTN search against sequences of selected Rfam families and the results were refined further using Cmsearch [58]. Clustered Regularly Interspaced Short Palindromic Repeats (CRISPRs) were identified by searching the CRISPR database with the CRISPRfinder program (http://crispr.u-psud. fr/Server/) [59-62].

\section{Genome properties}

The 2,715,909 bp $(32.75 \% \mathrm{G}+C)$ genome of $F$. psychrophilum ATCC $49418^{\mathrm{T}}$ contains 6 rRNA operons and 49 tRNA genes and is predicted to encode 2329 proteins (Figure 3

Table 5 Some putative virulence factors of F. psychrophilum ATCC 49418

\begin{tabular}{llll}
\hline Locus tag & Gene name & Family & Product \\
\hline FPG3_00455 & M50 & M12B & Putative zinc metalloprotease \\
FPG3_01260 & fpp1 & M43 & Psychrophilic metalloprotease Fpp1 precursor \\
FPG3_01265 & Zpp2 & Zn Peptidase & Psychrophilic metalloprotease Fpp2 precursor \\
FPG3_06120 & HlyD2 & Putative neutral zinc metallopeptidase \\
FPG3_06485 & hlyD & HlyD2 & Putative hemolysin D transporter \\
FPG3_10400 & hlyD & MntH & Putative hemolysin D transmembrane transporter \\
FPG3_00420 & & FeoA & Mn ${ }^{2+}$ and Fe ${ }^{2+}$ transporter of the NRAMP family \\
FPG3_00490 & FeoB & Iron transport protein A \\
FPG3_00495 & Peptidase M75 & Iron transport protein B \\
FPG3_04340 & TM-ABC Iron Siderophore & Iron-regulated protein A precursor \\
FPG3_04455 & FeoB & ABC iron transporter system, permease component \\
FPG3_05120 & CCC1 & ABC iron transporter system, binding protein precursor \\
FPG3_06195 & Plant peroxidase like & Probable iron transporter \\
FPG3_09395 & LRR5 & Hydroperoxidase with catalase and peroxidase activities \\
FPG3_00925 & LRR5 & Cell surface protein precursor with leucine rich repeats \\
FPG3_00930 & LRR5 & Cell surface protein precursor with leucine rich repeats \\
FPG3_00935 & LRR5 & Cell surface protein precursor with leucine rich repeats \\
FPG3_00940 & & Cell surface protein precursor with leucine rich repeats \\
\hline & &
\end{tabular}


and Table 3). No plasmids were identified during the annotation process. The distribution of genes into COG functions is shown in Table 4. When compared to the JIP02/86 strain, ATCC $49418^{\mathrm{T}}$ had fewer proteins classified as "not in COGs" (43.8\% vs. $47.5 \%)$ and had slightly more replication, repair, and recombination COGs (96 vs. 82). The two strains differed little in other COG categories. The Average Nucleotide Identity (ANI) between ATCC $49418^{\mathrm{T}}$ and JIP02/86 was calculated to be $99.34 \%(+/-1.83 \%)$ and $99.37 \%(+/-1.71 \%)$ one way and $99.43 \%(+/-1.51 \%)$ two way [63]. The estimated distance to distance hybridization (DDH) values between the two strains was calculated to be $96.20 \%(+/-1.16 \%)$ and the distance was 0.0053 . The probability that $\mathrm{DDH}>70 \%$ (i.e. same species) is $97.48 \%$ [64].

\section{Insights into the genome sequence}

A number of studies have been done to determine the pathogenesis of F. psychrophilum but, to date, the exact mechanisms are still unknown [1]. Some putative and previously characterized virulence factors are listed in Table 5. Proteolytic enzymes are widely used by fish pathogens to cause tissue damage and allow invasion of the host [1]. In the F. psychrophilum ATCC $49418^{\mathrm{T}}$ genome there are four metalloprotease encoding genes including a predicted zinc metalloprotease [FPG3_00455], a predicted zinc peptidase [FPG3_06120] and the previously reported Fpp1 [66] and Fpp2 [67] metalloproteases. Rainbow trout with RTFS are anemic and past studies have reported that the red blood cells of rainbow trout are partially lysed when infected by F. psychrophilum $[68,69]$. Homologs of two RTX hemolysin transporters (FPG3_06485, FPG3_10400) were identified, but did not appear to be linked to any toxin or modification genes [70]. Six iron transport genes were also identified; these were anticipated since iron uptake is a well-known characteristic of most pathogens. Moreover, recent research has shown that attenuated F. psychrophilum strains cultured under iron limiting conditions confer greater protection to fish when used as an experimental vaccine [71]. A hydroperoxidase with predicted catalase and peroxidase functions were also identified. In addition, there are 11 cell surface proteins with leucine rich repeats that are predicted to be adhesins; several are listed in Table 5. These were very similar to the ones found in F. psychrophilum JIP/02. Further research is required to determine what functions these adhesins have and how they help F. psychrophilum bind to the host.

\section{Conclusion}

Flavobacterium psychrophilum, the causative agent of BCWD and RTFS in salmonid fishes, causes significant economic losses in the aquaculture industry. The genome sequence of the ATCC $49418^{\mathrm{T}}$ strain will hopefully provide new insights into virulence mechanisms and pathogenesis of F. psychrophilum and help in the identification of suitable targets for vaccines and antimicrobial agents; however, to do this much more analysis will be required.

\section{Abbreviations \\ BCWD: Bacterial cold water disease; RTFS: Rainbow trout fry mortality syndrome.}

\section{Competing interests}

The authors declare that they have no competing interests.

\section{Authors' contributions}

AW participated in genome sequencing analysis, bioinformatics analysis, drafted the original manuscript, and participated in the revision process. AK participated in genome sequence analysis and assembly refinement. $J$ and $\mathrm{BD}$ participated in the study design and provided funding for the project. JM conceived the study, provided funding for the project, and participated in the revision process. All authors read and approved the final manuscript.

\section{Acknowledgements}

This work was supported by a grant from the Natural Sciences and Engineering Council entitled "Immunity, vaccination and rainbow trout family susceptibility to Flavobacterium psychrophilum". We thank Glenn Soltes for expert technical help.

\section{Author details}

${ }^{1}$ Department of Pathobiology, Ontario Veterinary College, University of Guelph, 50 Stone Road East, Guelph, Ontario N1G 2W1, Canada. ²Department of Biology, 200 University Avenue West, Waterloo, Ontario N2L 3G1, Canada.

Received: 3 July 2014 Accepted: 21 November 2014

Published: 21 January 2015

\section{References}

1. Nematollahi A, Decostere A, Pasmans F, Haesebrouck F. Flavobacterium psychrophilum infections in salmonid fish. J Fish Dis. 2003; 26(10):563-74. http://dx.doi.org/10.1046/j.1365-2761.2003.00488.x.

2. Austin B, Austin DA. Bacterial fish pathogens: Disease of farmed and wild fish. Thirdth ed. Chichester: Praxis Publishing; 1999.

3. Lehmann J, Mock D, Stiirenberg F, Bernardet J. First isolation of Cytophaga psychrophila from a systemic disease in eel and cyprinids. Dis Aquat Org. 1991; 10:217-20. http://dx.doi.org/10.3354/dao010217.

4. Noga EJ. Fish disease: Diagnosis and treatment. Ames, lowa: Wiley-Blackwell; 2010.

5. Holt RA. Cytophaga psychrophila, the causative agent of bacterialcold water disease in salmonid fish. In: PhD thesis. University of Oregon; Oregon, USA: 1987.

6. Anderson II, Conroy DA. The pathogenic myxobacteria with special reference to fish diseases. J Appl Bacteriol. 1969; 32(1):30-9.

7. Barnes ME, Brown ML. A review of Flavobacterium psycrhophilum biology, clinical, signs, and bacterial cold water disease prevention and treatment. Open Fish Sci J. 2011; 4:1-9.

8. Hesami S, Allen KJ, Metcalf D, Ostland VE, Maclnnes JI, Lumsden JS. Phenotypic and genotypic analysis of Flavobacterium psychrophilum isolates from ontario salmonids with bacterial coldwater disease. Can J Microbiol. 2008; 54(8):619-29.

9. Nagai T, Nakai T. Growth of Flavobacterium psychrophilum in fish serum correlates with pathogenicity. J Fish Dis. 2011; 34(4):303-10. http://dx.doi. org/10.1111/j.1365-2761.2011.01245.x.

10. Chakroun C, Grimont F, Urdaci MC, Bernardet JF. Fingerprinting of Flavobacterium psychrophilum isolates by ribotyping and plasmid profiling. Dis Aquat Organ. 1998; 33(3):167-77.

11. Nagata EF, Darmon CC, Bernardet JF, Eguchi M, Duchaud E, Nicolas P. Population structure of the fish pathogen Flavobacterium psychrophilum at whole-country and model river levels in Japan. Vet Res. 2013; 44:34-42. 
12. Sundell K, Heinikainen S, Wiklund T. Structure of Flavobacterium psychrophilum populations infecting farmed rainbow trout Oncorhynchus mykiss. Dis Aquat Organ. 2013; 103(2):111-19.

13. Nilsen H, Sundell K, Duchaud E, Nicolas P, Dalsgaard I, Madsen L, Aspan A, Jansson E, Colquhoun DI, Wiklund T. Multilocus sequence typing identifies epidemic clones of Flavobacterium psychrophilum in nordic countries. Appl Environ Microbiol. 2014; 80(9):2728-36.

14. Duchaud E, Boussaha M, Loux V, Bernardet J, Michel C, Kerouault B, Mondot S, Nicolas P, Bossy R, Caron C, Bessières P, Gibrat JF, Claverol S, Dumetz F, Le Hénaff $M$, Benmansour A. Complete genome sequence of the fish pathogen Flavobacterium psychrophilum. Nat Biotechnol. 2007; 25(7):763-69. http://dx.doi.org/10.1038/nbt1313.

15. Bernardet JF, Kerouault B. Phenotypic and genomic studies of "Cytophaga psychrophila" isolated from diseased rainbow trout (oncorhynchus mykiss) in France. Appl Environ Microbiol. 1989; 55(7):1796-800.

16. Borg AF. Studies on Myxobacteria associated with diseases in salmonid fishes. 8th ed. Washington, D.C: American Association for the Advancement of Science; 1960.

17. Bernardet JF, Grimont PAD. Deoxyribonucleic acid relatedness and phenotypic characterization of Flexibacter columnaris sp. nov., nom. rev., Flexibacter psychrophilus sp. nov., nom. rev., and Flexibacter maritimus wakabayashi, hikida, and masumura. Int J Syst Bacteriol. 1989; 39(3):346-54 http://dx.doi.org/10.1099/00207713-39-3-346.

18. Bernardet JF, Segers P, Vancanneyt M, Berthe F, Kersters K, Vandamme P. Cutting a gordian knot: Emended classification and description of the genus Flavobacterium, emended description of the family Flavobacteriaceae, and proposal of Flavobacterium hydatis nom. nov. (basonym, Cytophaga aquatilis strohl and tait 1978). IntJSystBacteriol. 1996; 46(1):128-48. http://dx.doi.org/10.1099/00207713-46-1-128.

19. Euzeby JP. List of bacterial names with standing in nomenclature: $A$ folder available on the internet. Int J Syst Bacteriol. 1997; 47(2):590-92.

20. Schlegel HG. General microbiology. 7th ed. Cambridge, U.K: Cambridge University Press; 1993.

21. Parker CT, Wigley S, Garrity GM. Taxonomic Abstract for the genus Flavobacterium. In: Parker CT, Garrity GM, editors. The NamesforLife Abstracts [Internet]. NamesforLife, LLC; Available from: http://dx.doi.org/ $10.1601 /$ tx.8071

22. Bernardet JF. Family I. Flavobacteriaceae reichenbach 1992b, 327VP (effective publication: Reichenbach 1989b, 2013.) emend. Bernardet, Segers, Vancanneyt, Berthe, Kersters and Vandamme 1996, 145 emend. Bernardet, Nakagawa and Holmes 2002, 1057. In: Krieg NR, Staley JT, Brown DR, Hedlund BP, Paster BJ, Ward NL, Ludwig W, Whitman WB, editors. Bergey's manual of systematic bacteriology, Volume 4. Secondth ed. New York: Springer; 2010: p. 106.

23. Bernardet JF. Order I. Flavobacteriales ord. nov. In: Krieg NR, Staley JT, Brown DR, Hedlund BP, Paster BJ, Ward NL, Ludwig W, Whitman WB, editors. Bergey's manual of systematic bacteriology, Volume 4. Secondth ed. New York: Springer; 2010: p. 105.

24. Woese $C R$, Kandler $\mathrm{O}$, Wheelis ML. Towards a natural system of organisms: Proposal for the domains Archaea, bacteria, and Eucarya. Proc Natl Acad Sci U S A. 1990; 87(12):4576-79. http://www.ncbi.nlm.nih.gov/pmc/articles/ PMC54159/.

25. Krieg NR, Ludwig W, Euzéby J, Whitman WB. Phylum XIV. Bacteroidetes phyl. nov. In: Krieg NR, Staley JT, Brown DR, Hedlund BP, Paster BJ, Ward NL, Ludwig W, Whitman WB, editors. Bergey's manual of systematic bacteriology, Volume 4. Secondth ed. New York: Springer; 2010: p. 25.

26. Validation list no. 145. list of new names and new combinations previously effectively, but not validly, published. Int Int J Syst Evol Microbiol. 2012; 62:1017-19. http://ijs.sgmjournals.org/content/62/Pt_5/1017.full.

27. Bernardet JF. Class II. Flavobacteriia class. nov. In: Krieg NR, Staley JT, Brown DR, Hedlund BP, Paster BJ, Ward NL, Ludwig W, Whitman WB, editors. Bergey's manual of systematic bacteriology, Volume 4. Secondth ed. New York: Springer; 2010: p. 105.

28. Reichenbach H. Genus 1. Cytophaga Winogradsky $1929,577^{A L}$, emend. In: Staley JT, Bryant MP, Pfennig N, Holt JG, editors. Bergey's manual of systematic bacteriology, Volume 3. Baltimore: The Williams \& Wilkins Co; 1989: p. 2015-50.

29. Pacha RE. Characteristics of Cytophaga psychrophila (borg) isolated during outbreaks of bacterial cold-water disease. Appl Microbiol. 1968; 16(1):97-101.

30. Cepeda C, Garci'a-Márquez S, Santos Y. Improved growth of Flavobacterium psychrophilum using a new culture medium. Aquaculture 2004; 238(1-4):75-82. http://dx.doi.org/10.1016/j.aquaculture.2004.05.013.
31. Holt RA, Amandi A, Rohovec JS, Fryer UL. Relation of water temperature to bacterial cold water disease in coho salmon, chinook salmon, rainbow trout. J Aquat Anim Health. 1989; 1:94-101.

32. Uddin MN, Wakabayashi $\mathrm{H}$. Effects of temperature on growth and protease production of, Cytophaga psvchrophila. Fish Pathol. 1997; 32(4):225-26.

33. Bernardet JF, Bowman JP. The genus Flavobacterium. In: Dworkin M, Falkow S, Rosenberg E, Schleifer K, editors. The Prokaryotes. A handbook on the biology of bacteria: Proteobacteria: Delta and epsilon subclasses. deeply rooting bacteria, Volume 7. 3rd ed. New York: Springer; 2006: p. 486-509.

34. Pacha RE, Porter S. Characteristics of myxobacteria isolated from the surface of freshwater fish. Appl Microbiol. 1969; 16(12):1901-06.

35. Bertolini JM, Wakabayashi H, Watral VG, Whipple MJ, Rohovec JS. Electrophoretic detection of proteases from selected strains of Flexibacter psychrophilus and assessment of their variability. JAquatAnimHealth. 1994; 6(3):224-33. http://www.tandfonline.com/doi/abs/ 10.1577/1548-8667\%281994\%29006\%3C0224\%3AEDOPFS\%3E2.3.CO\%3B2? $a i=t 8 b z \& m i=b k e r q n \& a f=R$.

36. Ostland VE, Byrne PJ, Hoover G, Ferguson HW. Necrotic myositis of rainbow trout,Oncorhynchus mykiss (walbaum): Proteolytic characteristics of a crude extracellular preparation from Flavobacterium psychrophilum. JFish Dis. 2000; 23(5):329-36. http://dx.doi.org/10.1046/j.1365-2761.2000.00251.x.

37. Moller JD, Ellis AE, Barnes AC, Dalsgaard I. Iron acquisition mechanisms of Flavobacterium psychrophilum. JFish Dis. 2005; 28(7):391-98. http://dx.doi. org/10.1111/j.1365-2761.2005.00639.x.

38. Otis EJ. Lesions of cold water disease in steelhead trout (Salmo gairdneri): The role of Cytophaga psychrophila extracellular products. MSc thesis: University of Rhode Island; 1984

39. Holt RA, Rohovec JS, Fryer JL. Bacterial cold-water disease. In: Inglis V Roberts RJ, Bromage NR, editors. Bacterial diseases of fish. Oxford: Blackwell Scientific Publications; 1993: p. 3-23.

40. Ashburner M, Ball CA, Blake JA, Botstein D, Butler H, Cherry JM, Davis AP, Dolinski K, Dwight SS, Eppig JT, Harris MA, Hill DP, Issel-Tarver L, Kasarskis A, Lewis S, Matese JC, Richardson JE, Ringwald M, Rubin GM, Sherlock G. Gene ontology: Tool for the unification of biology. the gene ontology consortium. Nat Genet. 2000; 25(1):25-9.

41. Dereeper A, Guignon V, Blanc G, Audic S, Buffet S, Chevenet F, Dufayard JF, Guindon S, Lefort V, Lescot M, Claverie JM, Gascuel O. Phylogeny.fr: Robust phylogenetic analysis for the non-specialist. Nucleic Acids Res. 2008; 36(Web Server issue):W465-9.

42. Edgar RC. MUSCLE: Multiple sequence alignment with high accuracy and high throughput. Nucleic Acids Res. 2004; 32(5):1792-97. http://dx.doi.org/ 10.1093/nar/gkh340.

43. Castresana J. Selection of conserved blocks from multiple alignments for their use in phylogenetic analysis. Mol Biol Evol. 2000; 17(4):540-52.

44. Guindon S, Gascuel O. A simple, fast, and accurate algorithm to estimate large phylogenies by maximum likelihood. SystBiol. 2003; 52(5):696-704. http://dx.doi.org/10.1080/10635150390235520.

45. Chevenet F, Brun C, Banuls AL, Jacq B, Christen R. TreeDyn: Towards dynamic graphics and annotations for analyses of trees. BMC Bioinformatics. 2006; 7:439.

46. NCBI Prokaryotic Genome Annotation Pipeline. http://www.ncbi.nlm.nih.gov/ genome/annotation_prok/.

47. Field D, Garrity G, Gray T, Morrison N, Selengut J, Sterk P, Tatusova T, Thomson N, Allen MJ, Angiuoli SV, Ashburner M, Axelrod N, Baldauf S, Ballard S, Boore J, Cochrane G, Cole J, Dawyndt P, De Vos P, dePamphilis C, Edwards R, Faruque N, Feldman R, Gilbert J, Gilna P, Glockner FO, Goldtein P, Guralnick R, Half D, Hancock $D$, et al. The minimum information about a genome sequence (MIGS) specification. Nat Biotechnol. 2008; 26(5):541-47.

48. Anacker RL, Ordal EJ. Studies on the myxobacterium Chondrococcus columnaris. I. serological typing. J Bacteriol. 1959; 78(1):25-32.

49. Chin CS, Alexander DH, Marks P, Klammer AA, Drake J, Heiner C, Clum A Copeland A, Huddleston J, Eichler EE, Turner SW, Korlach J. Nonhybrid, finished microbial genome assemblies from long-read SMRT sequencing data. Nat Methods. 2013; 10(6):563-69.

50. Chaisson MJ, Tesler G. Mapping single molecule sequencing reads using basic local alignment with successive refinement (BLASR): Application and theory. BMC Bioinformatics. 2012; 13:238-2105-13-238.

51. PBDAG-Con. https://github.com/PacificBiosciences/pbdagcon.

52. Chain PS, Grafham DV, Fulton RS, Fitzgerald MG, Hostetler J, Muzny D, Ali J, Birren B, Bruce DC, Buhay C, Cole JR, Ding Y, Dugan S, Field D, Garrity GM, Gibbs R, Graves T, Han CS, Harrison SH, Highlander S, Hugenholtz P, Khouri 
HM, Kodira CD, Kolker E, Kyrpides NC, Lang D, Lapidus A, Malfatti SA Markowitz V, Metha T, et al. Genomics. genome project standards in a new era of sequencing. Science. 2009; 326(5950):236-37.

53. Lee $C$, Grasso C, Sharlow MF. Multiple sequence alignment using partial order graphs. Bioinformatics. 2002; 18(3):452-64. http://dx.doi.org/10.1093/ bioinformatics/18.3.452

54. Angiuoli SV, Gussman A, Klimke W, Cochrane G, Field D, Garrity G, Kodira CD, Kyrpides N, Madupu R, Markowitz V, Tatusova T, Thomson N, White O. Toward an online repository of standard operating procedures (SOPs) for (meta) genomic annotation. OMICS. 2008; 12(2):137-41.

55. Wheeler DL. Database resources of the national center for biotechnology information. Nucleic Acids Res. 2006; 34(90001):173-80. http://dx.doi.org/ 10.1093/nar/gkj158.

56. Besemer J, Lomsadze A, Borodovsky M. GeneMarkS: A self-training method for prediction of gene starts in microbial genomes. implications for finding sequence motifs in regulatory regions. Nucleic Acids Res. 2001; 29(12):2607-18

57. Lowe TM, Eddy SR, tRNAscan-SE. A program for improved detection of transfer RNA genes in genomic sequence. Nucleic Acids Res. 1997; 25(5):955-64. http://dx.doi.org/10.1093/nar/25.5.0955.

58. Griffiths-Jones S, Rfam. An RNA family database. Nucleic Acids Res. 2003; 31(1):439-41. http://dx.doi.org/10.1093/nar/gkg006.

59. Rousseau C, Gonnet M, Le Romancer M, Nicolas J. CRISPI: A CRISPR interactive database. Bioinformatics. 2009; 25(24):3317-18.

60. Grissa I, Vergnaud G, Pourcel C. The CRISPRdb database and tools to display CRISPRs and to generate dictionaries of spacers and repeats. BMC Bioinformatics. 2007; 8:172-82.

61. Grissa I, Vergnaud G, Pourcel C. CRISPRFinder: A web tool to identify clustered regularly interspaced short palindromic repeats. Nucleic Acids Res. 2007; 35:W52-7.

62. Grissa I, Vergnaud G, Pourcel C. CRISPRcompar: A website to compare clustered regularly interspaced short palindromic repeats. Nucleic Acids Res. 2008; 36:W145-8.

63. ANI. Average Nucleotide Index. http://enve-omics.ce.gatech.edu/ani/index.

64. Auch AF, von Jan M, Klenk HP. Digital DNA-DNA hybridization for microbial species delineation by means of genome-to-genome sequence comparison. Stand Genomic Sci. 2010; 2(1):117-34.

65. Stothard $\mathrm{P}$, Wishart DS. Circular genome visualization and exploration using CGView. Bioinformatics. 2004; 21(4):537-39. http://dx.doi.org/10.1093/ bioinformatics/bti054.

66. Secades P, Alvarez B, Guijarro JA. Purification and characterization of a psychrophilic, calcium-induced, growth-phase-dependent metalloprotease from the fish pathogen Flavobacterium psychrophilum. Appl Environ Microbiol. 2001; 67(6):2436-44.

67. Secades P, Alvarez B, Guijarro JA. Purification and properties of a new psychrophilic metalloprotease (Fpp2) in the fish pathogen Flavobacterium psychrophilum. FEMS MicrobiolLett. 2003; 226(2):273-79. http://dx.doi.org/10.1016/s0378-1097(03)00599-8.

68. Lorenzen E. Study on Flexibacter psychrophilus in relation to rainbow trout fry syndrome (RTFS). PhD thesis. Royal Veterinary and Agricultural University; Copenhagen, Denmark: 1994

69. Lorenzen $\mathrm{E}$, Olesen N. Characterization of isolates of Flavobacterium psychrophilum associated with coldwater disease or rainbow trout fry syndrome:Serological studies. DisAquatOrg. 1997; 31:209-20. http://dx.doi. org/10.3354/dao031209.

70. Koronakis V, Cross M, Senior B, Koronakis E, Hughes C. The secreted hemolysins of Proteus mirabilis, Proteus vulgaris, and Morganella morganil are genetically related to each other and to the alpha-hemolysin of Escherichia coli. J Bacteriol. 1987; 169(4):1509-15.

71. Long A, Fehringer TR, Swain MA, LaFrentz BR, Call DR, Cain KD. Enhanced efficacy of an attenuated Flavobacterium psychrophilum strain cultured under iron-limited conditions. Fish Shellfish Immunol. 2013; 35(5):1477-82.

doi:10.1186/1944-3277-10-3

Cite this article as: Wu et al:: Complete genome sequence of the fish pathogen Flavobacterium psychrophilum ATCC $49418^{\top}$. Standards in Genomic Sciences 2015 10:3.

\section{Submit your next manuscript to BioMed Central and take full advantage of:}

- Convenient online submission

- Thorough peer review

- No space constraints or color figure charges

- Immediate publication on acceptance

- Inclusion in PubMed, CAS, Scopus and Google Scholar

- Research which is freely available for redistribution

Submit your manuscript at www.biomedcentral.com/submit
C Biomed Central 